\title{
Autoregulators in the housing market financing system: a structurally functional approach
}

\author{
Denis Ushakov, ${ }^{1, *}$, and Mariia Ermilova ${ }^{2}$ \\ ${ }^{1}$ IC, Suan Sunandha Rajabhat University, 1 U-Thong Nok rd, 10200 Dusit, Bangkok, Thailand \\ ${ }^{2}$ Plekhanov Russian University of Economics, Department of financial management, 117997, \\ Moscow, Russia
}

\begin{abstract}
The housing market is one of the most important segments of the economy of any country. As part of the study, it is shown that it is not enough to consider the housing market financing system only in the organizational and structural aspect. The application of a structurally functional approach is essential, which will improve the efficiency of market financing. The author determines the need for the formation of auto-regulators that can reduce the need for manual control of the economy of the housing complex and the state, which is especially important in the modern economic system. The study identified such auto-regulators as the inclusion of borrowers in the quality management system and the usefulness of housing finance; organization of interaction of market and state financing based on the principles of public-private partnership; the need for a system of indicators to assess the development of the Russian housing market, improving the information support of financial markets; the formation of an open system for monitoring the status of the housing market financing system.
\end{abstract}

\section{Introduction}

Processes in the housing market, including those associated with the financing of operations and transactions in it, have a significant impact on the economic development of the country and on the welfare of its population. In world practice, the Global Built Asset indicator is used, which determines the welfare of a country based on an assessment of the value of all real estate in the country, including infrastructure, residential and commercial real estate. The given coefficient takes into account the provision of citizens of the country with these facilities. According to the UN forecast, by 2050 it is planned another boom in world population growth by $33 \%$, which will increase the housing stock and the number of jobs.

In a modern economy, a system of financing markets, industries, etc. consider in the organizational and structural aspect, that is, from the point of view of the elements of a given financing system, the relationships between these elements and this entire system as a whole with the external environment.

${ }^{*}$ Corresponding author: denis.us@ssru.ac.th 
However, it should be borne in mind that with the improvement of the internal organization of the elements of the financing system and their interaction among themselves, the potential for return to the internal and external environment decreases and then other approaches are needed.

One solution may be a system-functional approach. In the framework of his methodology, the selection of development autoregulators is seen as important. The effect of improving the strategic management of the housing complex and the entire economy based on their integration into the housing market financing system. Thus, this will reduce the need for manual management of the economy of the housing complex and the state.

In the framework of this study, the goal is to highlight development autoregulators in the housing market financing system as tools for its effectiveness.

To achieve this goal it is supposed to solve the following tasks:

- analyze the concept of financing the housing market;

- to reveal the essence of a system-functional approach in relation to housing market financing;

- highlight the main autoregulators of development in the market financing system.

Analyzing the existing studies, it should be noted that the authors pay much attention to the structurally-element-wise aspect when evaluating the financing of processes in the housing market. Many works are devoted to separate financial instruments that allow financing operations in the housing market. As such, autoregulators of development that will reduce the need for manual market management and increase the efficiency and quality of its management are not highlighted.

The structural and functional approach was considered in relation to the economic infrastructure of the region [1], where the author forms its structural and functional study scheme and determines the contour mechanism of functioning.

The most related area where a system-functional approach was applied was applied to housing and communal services [2], through which the development of the processes for providing utility services was disclosed, which was able to resolve conflict situations in this area.

As such, the concept of autoregulators of development is not widely represented in existing studies. However, specific concepts that can be attributed to autoregulators are disclosed. For example, state regulation and public-private partnerships in the housing market [3]. Researchers based on the results of the study conclude that it is advisable to use public-private partnership tools on the regional residential real estate market in combination with the development and implementation of a comprehensive rural development program for the region.

A number of foreign authors [4] see the importance of cyclical analysis in the housing market, which undoubtedly has a significant impact on the development of financing and the functioning of the market.

Another important area is the identification of indicators for assessing the development of the Russian housing market, attempts to form which were undertaken by a number of researchers who highlighted housing affordability [5]. It is important to highlight the list of indicators.

Zhu B., Betzinger M., Sebastian S. [6] associate stability in the housing market with a specific monetary policy and structure of the mortgage market. This is a more extended list of indicators than previously mentioned authors. Scharfstein D., Sunderam A. also analyze mortgage market indicators and monetary policy, highlighting them as significant factors for the housing market [7].

A number of researchers pay more attention to price factors influencing the development of the housing market and its financing, putting prices in priority [8], [9]. 
Grinenko S. [10] and Poorvu, W.J. [11] provide a wider list of indicators for assessing the development of the housing market, including in terms of the investment component. However, as well as other authors, they do not give such a definition as an autoregulator, which becomes especially relevant for the modern development of the housing market.

Shim I., Bogdanova A, Shek J., Subelyte A. [12] in their studies cite a rather large number of indicators, but do not distribute them in specific areas and do not focus on the significance of their influence on the market as a whole.

Ermilova M., Finogenova Y. in their work focus more on the analysis of macroeconomic factors and their impact on the housing market, on pricing on it [13].

Research by Canepa A., Khaled F. [14] and Berg N., Jha N., Murdoch J.C. [15] focus on the need to especially consider the risks that may arise in the housing market in the process of financing and functioning. Certain species by the authors stand out in their works. However, they are distinguished as certain factors and a grouping is not made that allows them to be attributed to some kind of autoregulator

In general, in these studies, the definition of these indicators as auto-regulators of the development of housing market financing was not carried out. Although this is an important direction in the light of a systematic approach, which increases the effectiveness of financing in general [16].

Thus, we see the need for a system-functional analysis of the financing system for operations in the housing market, as well as the allocation of a list of auto regulators that will improve the quality of this financing.

\section{Methods}

In the course of the study, the rationale for the concept of financing the housing market seems initially appropriate.

As noted earlier, most often the financing system of something, whether it is an industry, market, cluster, etc. considered in the organizational and structural aspect. Such a theoretical and methodological approach to research is productive for solving the problems of identifying internal contradictions, inconsistencies of individual elements of financing systems to each other, as well as their interaction with each other. The main tasks and problems are in the internal organization of the financing system (the financial system of a particular economic object).

Thus, it is explicitly or implicitly assumed that initially the elements of the financing system were and are in a state of incomplete mutual correspondence, there are hidden and obvious contradictions between them, and their interaction is very imperfect. - This state of the financial system (or financing system is characteristic of the initial stages of its development: formation, formation.

The second thing that is supposed to be: the elimination of internal discrepancies, contradictions between the elements of the financing system, the justification and, on this basis, the construction of a more perfect system of interaction between the elements of the system among themselves will lead to the fact that this system as a whole, being an organizing (financial) form in relation to economic content (non-financial economy of a country, industry, economic complex, cluster, large organization, etc.) will contribute to the development of this economic content - internally and external economic environment of the financial system (financial system).

Such expectations are fully justified, but the magnitude of the expected effect of this kind of research will be significantly different at different stages of development of the financial system. At the initial stages of development: at the stages of formation and formation, the degree of mutual inconsistency, contradictions in the internal organization of 
the financing system - more. Accordingly, the return on eliminating inconsistencies and contradictions is all the stronger.

However, as the internal organization of the elements of the financing system and their interaction among themselves become more and more perfect, the potential for the return of improving this system to the internal and external economic environment decreases and weakens. Other approaches to financial research are required.

The fact that the element-wise approach to financial research was outside the scope of the main concept: the specific nature and mechanism of the impact of the entire financing system and its individual elements on the surrounding internal and external economic environment - should now become the main subject of research: only in this way effectiveness the effects of the financial system on the development of economic complexes at various levels can be clearly identified and radically increased. Studying the financing mechanism, in terms of its impact on the housing market, on the development of the housing complex based on the structural-element approach is unproductive.

The solution of this kind of problems - increasing the effectiveness of the positive impact of the impact of financial systems of various levels on economic and economic processes, complexes, clusters - requires fundamentally different theoretical and methodological approaches. We study the impact of the financing system - the (financial) form of organizing the housing market on the economic content of this market. The form is represented by different elements of the financing system, each of which operates in a different way. And the content: the housing market - is represented by many economic elements, each of which affects the elements of the form and is influenced by each of the elements of the form.

One of the possible approaches to solving such problems is system-functional. The methodology of the system-functional analysis of the housing market financing system involves:

1. The influence of each element of the form on each element of the content cannot be immediately distinguished from the whole set of mutual influences of the elements of content and form. Initially, consideration of the impact of financing as a holistic single system, which in a certain way affects the development of the housing market (because it is impossible to immediately isolate the results, the effects of individual structural elements of the system on the development of the housing market or housing complex). That is, at first, the financing system is considered as an undivided whole of the housing complex: the complex includes its economic subsystem - the housing market - maintenance, and the organization of market financing - the financial form of its organization.

1) First, the undifferentiated results of the systemic effects of content and form on each other are determined.

2) Then, in the results - prints, changes in the content by characteristic features recognize the connection with the characteristic features of form elements. Thus, the qualitative aspects of the mutual or one-sided influence of the elements of the form on the content are determined.

3) System-functional analysis allows you to link the action of the individual elements of the form on the individual elements of the content and thus specify the content of the interconnection of the individual elements of the content and form.

4) System-functional analysis allows you to identify the composition of elements in individual episodes of the interaction of content and form. Thus, it can be a necessary step in the construction of statistical research models that determine the quantitative relationships between the elements of content and form in a holistic system. Without system-functional analysis, statistical analysis is much less productive.

5) After establishing the composition of the interacting elements, it becomes possible to study the strength, intensity and characteristics of the interaction between the individual 
elements of the system, to identify how to change, to give a more productive character to this interaction.

6) Finally, as a result of these studies, it becomes possible to justify systemic changes in the elements of the form in order to make the effect of the form on the content even more productive.

7) In order to apply a productive system-functional analysis to the study of the housing market financing system, it is necessary:

A) to consider the organization of financing the housing market first as a single form organizing the economic content - the housing market; the unity of form and content can be represented as a housing complex;

B) consider the housing complex as a complex organic self-developing system, gradually changing the nature of the relationship between its elements and between its elements and premises;

C) identify the characteristic repeated actions (functions, effects) of the financial form (financing system) on the economic content (condition and development of the housing market);

D) determine the channels (methods) through which this effect is carried out;

E) to establish how it is possible to enhance the productive effect of form elements through identified channels (interest rates, managing the aggregate utility of housing, managing the flexibility and information efficiency of the housing market financing system), seeking to improve the performance of the economic system;

E) determine how the financing system as a whole (the financial form of the housing complex) should change so that its impact on the economic content (housing market) and the entire system (housing complex) becomes more effective;

$\mathrm{G})$ in developing organic systems, their structuring form changes in such a way that at the stage of its maturity, its positive impact on the development of content and the whole system (the housing complex) is enhanced. It is necessary to understand how, thanks to which this happens and how it can be used in practice;

$\mathrm{H}$ ) in developed organic systems (for example, the human body), the effect of the structuring form (nervous system) on the human body occurs automatically and regulates itself. Therefore, it is necessary to find autoregulators of development built into it in the social organic system, to study them, finding ways to strengthen their positive impact on economic development. This will not only increase the efficiency of the entire system - the housing complex, but also increase its manageability, reduce the need for "manual control" in the state, providing automatic adjustment of the system, with unpredictable changes in the development conditions of the financial and economic system (housing complex).

\section{Results}

Based on the analysis, it is advisable to identify the main functions that constantly renew the effects of the financing system on the processes and results of the housing complex:

- organization of reproduction, that is, distribution and influx into the sphere of production of economic resources in the required quantity and proportions; accordingly, violation of proportions, non-optimal proportions of attracting economic resources is a sign of inadequacy of the organization of the financing system to the needs of economic development. The proportions of the distribution of financial resources are determined by their prices, the total need for resources, the availability of alternatives, the comparative utility of the use of resources, the amount of financial resources and the cost of options for their use, the presence of quantitative restrictions on attracting financial resources, the cost of finished products and the cost of their production. 
- the choice of alternatives to the use of financial resources, based on an assessment of the effectiveness of their application, taking into account time and risk factors; if the wrong alternatives or not the best are constantly selected, this means that something is preventing the financing system from performing its functions optimally;

- the formation of market signals about preferences, the usefulness of products for consumers and bringing these signals to manufacturers;

- alignment of the imaginary, value structure of the product's utility with respect to its individual components with the actual structure of the utility of manufactured products;

- balancing the profitability and risks of using resources in accordance with the preferences of producers and buyers;

- organization of flows of constant Pareto-improvements in combining and applying resources in the long term.

It is significant that, in contrast to the functions of finance in the short term, the functions of finance in the process of strategic management of economic complexes have not been studied (table 1).

Table 1. Comparative characteristics of the functions of finance in the short term and in the process of financing housing market facilities.

\begin{tabular}{|c|c|c|l|}
\hline $\begin{array}{c}\text { Short-term } \\
\text { finance } \\
\text { function }\end{array}$ & Gist & $\begin{array}{c}\text { Finance function in the } \\
\text { financing process } \\
\text { housing market }\end{array}$ & \multicolumn{1}{|c|}{ Gist } \\
\hline Cumulative & $\begin{array}{c}\text { Cash } \\
\text { formation }\end{array}$ & $\begin{array}{c}\text { Reproduction } \\
\text { Organization }\end{array}$ & $\begin{array}{l}\text { Distribution and inflow into the sphere } \\
\text { of production of economic resources in } \\
\text { the required quantity and proportions }\end{array}$ \\
\hline Distribution & Use of funds & $\begin{array}{c}\text { The choice of alternatives } \\
\text { for the use of financial } \\
\text { resources }\end{array}$ & $\begin{array}{l}\text { It is determined taking into account the } \\
\text { assessment of time and risk factors. }\end{array}$ \\
\hline & $\begin{array}{c}\text { Capital } \\
\text { efficiency } \\
\text { monitoring }\end{array}$ & Signal function & $\begin{array}{l}\text { Formation of market signals about } \\
\text { preferences, product usefulness for } \\
\text { consumers and bringing these signals } \\
\text { to manufacturers }\end{array}$ \\
\hline & Structural function & $\begin{array}{l}\text { Alignment of the imaginary, value } \\
\text { structure of the product's utility with } \\
\text { respect to its individual components } \\
\text { with the actual structure of the utility of } \\
\text { manufactured products. }\end{array}$ \\
\hline & Balancing function & $\begin{array}{l}\text { Balancing profitability and risks of } \\
\text { using resources in accordance with the } \\
\text { preferences of producers and buyers }\end{array}$ \\
\hline & Organizational function & $\begin{array}{l}\text { Organization of flows of constant } \\
\text { Pareto-improvements in combining and } \\
\text { applying resources in the long run. }\end{array}$ \\
\hline
\end{tabular}

These tables indicate that it is for the housing market that functions are specified on the most important indicators that should be taken into account.

Based on these functions, auto-regulators of development can be determined, which are one of the areas of influence of the housing market financing system on the economic development of the country. 


\section{Discussions}

The study allows us to say that in the framework of the structural-functional approach, it is necessary to determine the development auto-regulators in the housing market financing system.

It is essential to integrate autoregulators into this system. These auto-regulators can reduce the need for manual control of the economy of the housing complex and the state, which is especially important in the modern economic system. In addition, the efficiency and quality of this management is increased.

So, imagine auto-regulators:

A) The inclusion of borrowers in the quality management system and the utility of housing finance;

B) Organization of interaction of market and state financing based on the principles of public-private partnership, a combination of competition and cooperation;

The state, as a market entity, decides on financing the housing market

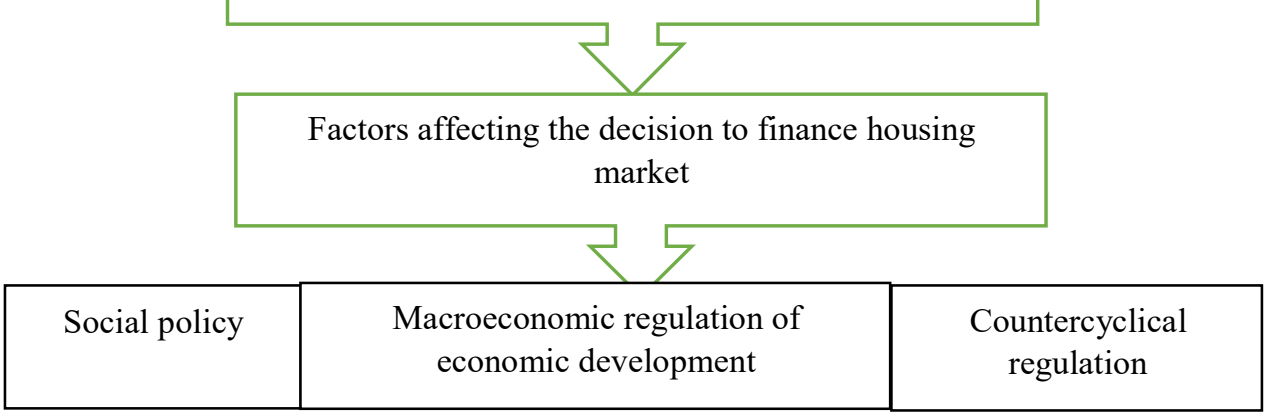

Fig. 1. Factors prompting the state to directly or indirectly influence housing market financing (Source: Authoring).

C) Build a system of indicators for assessing the development of the Russian housing market, the impact of its financing on the quality and other parameters of the housing complex, the incitement to international competition. Improving the information support of financial markets.

D) An open system for monitoring the status of the housing market financing system, organizing the impact of the housing market financing system on the housing market and housing construction.

One of the subjects of the housing market, as well as one of the operators of the mortgage market - the state-owned company Dom.RF (previously, the agency for mortgage lending) has already formed a certain monitoring system in the mortgage market (table 2). These parameters can be used to form a system for monitoring the functioning and financing of the housing market.

Assessing the data presented, we can say that they quite extensively reveal the provisions of the mortgage market in Russia. In this regard, it is important to use the data presented in the formation of a monitoring system for the development and financing of the housing market. Here it is worth supplementing it with the volume of square meters of housing introduced and withdrawn from circulation, information on market financing instruments other than mortgages. It will also be essential to include the dynamics of macroeconomic indicators, which most significantly affect the housing market. The whole 
system will be located on a specially developed single portal. The portal provides information on the marginal utility of a financing unit when it is invested in various components of the aggregate utility of housing. Thus, information from the portal can influence the decision-making on the distribution of economic resources in the increment of various components of the total utility of housing. When evaluating the effectiveness of housing projects, the distribution of financial resources is taken into account in the increment of various components of the total utility of housing. Independent experts can rate the comparative utility of the various components of housing utility in standard projects. According to this assessment, homebuilders can understand the increment of which components of the total utility of housing should be invested in the first place. You need to invest in those elements, components that are rated higher. This is a guideline for changing housing policies in the construction industry.

Table 2. Evaluation Dom.rf on the results of the functioning of the mortgage market

\begin{tabular}{|c|c|c|c|c|}
\hline & 2015 & 2016 & 2017 & 2018 \\
\hline \multicolumn{5}{|c|}{ Home mortgage loans } \\
\hline Volume, trillion rub. & 1.2 & 1.5 & 2.0 & 2.8 \\
\hline $\begin{array}{l}\text { Refinancing } * \text {, trillion } \\
\text { rub. }\end{array}$ & & $<0.03$ & $\begin{array}{l}0.15-0.2 \\
(400 \%)\end{array}$ & $\begin{array}{c}0.6 \\
(+300 \%)\end{array}$ \\
\hline $\begin{array}{l}\text { Quantity, thousand } \\
\text { pieces }\end{array}$ & 699.5 & $\begin{array}{c}856.5 \\
(+22.4 \%)\end{array}$ & $\begin{array}{c}1100 \\
(+28 \%)\end{array}$ & $\begin{array}{c}1600 \\
(+45 \%)\end{array}$ \\
\hline $\begin{array}{l}\text { Refinancing } \\
\text { thousand units }\end{array}$ & & 30 & $\begin{array}{l}130-180 \\
(+300 \%)\end{array}$ & $\begin{array}{c}500 \\
(+300 \%)\end{array}$ \\
\hline $\begin{array}{l}\text { Weighted average rate } \\
\text { in rubles, } \% \text { per annum }\end{array}$ & 13.4 & $\begin{array}{c}12.5 \\
(-0.9 \text { p.p.) }\end{array}$ & $\begin{array}{l}10.6-10.7 \\
\text { (-1.8 p.p.) }\end{array}$ & $\begin{array}{c}9 \\
\text { (-1.6 p.p.) }\end{array}$ \\
\hline $\begin{array}{l}\text { Average loan amount, } \\
\text { million rubles }\end{array}$ & 1.66 & $\begin{array}{c}1.72 \\
(+3.9 \%)\end{array}$ & $\begin{array}{c}1.85 \\
(+7.6 \%)\end{array}$ & $\begin{array}{c}1,75 \\
(-5.4 \%)\end{array}$ \\
\hline \multicolumn{5}{|c|}{ Mortgage loan portfolio } \\
\hline $\begin{array}{l}\text { Quantity, thousand } \\
\text { pieces }\end{array}$ & 4100 & $\begin{array}{c}4600 \\
(12 \%) \\
\end{array}$ & $\begin{array}{c}4800 \\
(+4 \%)\end{array}$ & $\begin{array}{l}5200 \\
(+8 \%)\end{array}$ \\
\hline Debt, trillion rub. & 4.1 & $\begin{array}{c}4,6 \\
(+12.6 \%)\end{array}$ & $\begin{array}{c}5.4 \\
(+17 \%)\end{array}$ & $\begin{array}{c}6.3 \\
(+17 \%) \\
\end{array}$ \\
\hline $\begin{array}{l}\text { Overdue } 90+\text {, billion } \\
\text { rubles. }\end{array}$ & 121 & $\begin{array}{c}119 \\
(-1.3 \text { p.p.) }\end{array}$ & $\begin{array}{c}120 \\
(+0,8 \text { p.p. })\end{array}$ & $\begin{array}{c}125 \\
(+4.2 \%)\end{array}$ \\
\hline$\%$ of the portfolio & 3.03 & $\begin{array}{c}2,65 \\
(-0.38 \text { p.p. })\end{array}$ & $\begin{array}{c}2.25 \\
(-0.4 \text { p.p. })\end{array}$ & $\begin{array}{c}2,0 \\
(-0.25 \text { p.p. })\end{array}$ \\
\hline
\end{tabular}

Source: ahml.ru

*There are no official statistics on refinancing volumes.

Thus, these auto-regulators will significantly improve the process of financing the housing market.

\section{Reference}

1. E. Khomenko,Rus. Entrepren.11 (11),113-116 (2010)

2. N. Komkov, T. Usmanova, D. Isakov, MIR 8 (4), 468-477 (2017)

3. E. Sotnikova E., I.Makarov I., Rus. Entrepren.16 (8), 1153-1164 (2015)

4. R. Reed R., H. Wu, Understanding property cycles in a residential market. Property management 28(1), 33-46 (2010)

5. D. Korolkova, N. Gerasimova, G. Tkachenko, Fund. Research 9(3), 635-638 (2014)

6. B. Zhu, M. Betzinger, S. Sebastian S., Journ. of Hous.Econ. 37, 1-21 (2017) 
7. D. Scharfstein D., A. Sunderam, Harvard University and NBER, 1-25(2014)

8. C. Basten, C. Koch, Jour.of Hous.Econ. 30, 1-22 (2015)

9. Q. Wei., X. Gu, Inter. Jour.of Appl.Math. and Stat. 49 (19), 26-33 (2013)

10. S. Grinenko, TRTU, 107 (2004)

11. W.J. Poorvu, Harvard Business School. July. 25 (2003)

12. I. Shim., A. Bogdanova, J. Shek., A. Subelyte. Database for policy actions on housing markets (2013)

13. M. Ermilova., Y. Finogenova,Inter. Jour. of Ecol. Econ. and Stat. 38( 2) 68-77 (2017)

14. A. Canepa, F. Khaled (2018).Inter. Jour. of Finan. Stud. 6 (50), 1-23 (2018)

15. N. Berg, Jha N., J.C. Murdoch, International Encyclopedia of Housing and Home 193203 (Elsevier, 2012)

16. L. Guzikova, I. Lukevich. EUrASEANs 1(8), 29 (2018). 